\title{
CALR NM_004343.3:C.1092_1143del52
}

National Cancer Institute

\section{Source}

National Cancer Institute. CALR NM 004343.3:C.1092 1143del52. NCI Thesaurus. Code C129834.

A deletion of 52 nucleotides from the coding sequence of the CALR gene from positions 1092 through 1143. 